AGH DRILLING, OIL, GAS • Vol. $34 \cdot$ No. $4 \cdot 2017$

http://dx.doi.org/10.7494/drill.2017.34.4.843

\author{
Albert Zlotkowski*, Angelika Druzgała*, Dagmara Zeljaś*
}

\title{
ANALYSIS OF ENERGY TRANSFER BETWEEN PIPES OF U-TYPE BOREHOLE HEAT EXCHANGER**
}

\section{INTRODUCTION}

Providing households and public utility objects with a source of energy for space heating is one of the main priorities of an investor. The increasing public awareness and legal regulations mean that more effective ways of the rational management of energy have to be sought, with the emphasis on renewable energy sources. Among the heating systems which are more and more frequently considered during the construction or renovation of buildings is a heating node equipped with a heat pump cooperating with borehole heat exchangers (BHE). This type of system remains competitive when compared to gas or oil boilers. The attractiveness of BHE-based systems may increase when the BHE efficiency is higher and the operating costs of the system go down $[2,3]$.

The main factor influencing operating cost is the achieved coefficient of performance (COP). A low value of this coefficient means that more electrical power is required to drive the heat pump. A high value of COP is influenced by the temperature of the heating factor of the building, and also the temperature of the energy carrier circulating in the BHE system. An increase of the temperature of the flowing factor inside the BHE is possible for the same amount of energy exchanged if the borehole heat exchanger is properly designed $[8,11]$.

The focus is on achieving the lowest possible thermal resistance of BHE and the elimination of heat transfer phenomena between the borehole pipes. This problem has a numerical description, which shows that there is a heat flow between the branches during BHE operation [5]. It has also been found that the best solution is to place the racks at the greatest distance possible in the hole [1].

The laboratory test on thermal energy transfer between the borehole pipes of a single type of a u-tube is presented in this paper.

* AGH University of Science and Technology, Faculty Drilling, Oil and Gas, Krakow, Poland

** Paper prepared within the research program No. 15.11.190.623. Work performed at the Department of Drilling and Geoengineering, Faculty of Drilling, Oil and Gas, AGH UST within Statutory Research Program No. 11.11.190.555 


\section{THE CONSTRUCTION OF BOREHOLE HEAT EXCHANGERS}

Borehole heat exchangers are made as intermediary elements for low temperature energy transfer between the receiver on the surface (heat pump) and the energy reservoir (rock mass). The most popular design of borehole heat exchanger is a u-tube made of plastic (polyethylene an external diameter of $40 \mathrm{~mm}$ ) consolidated with the rock mass by means of cement slurry. The whole is installed at the borehole $143-171 \mathrm{~mm}$ in diameter and $30 \mathrm{~m}$ to $180 \mathrm{~m}$ of depth. Borehole pipes are maintained at a constant distance from each other (from $50 \mathrm{~mm}$ to $100 \mathrm{~mm}$ from the axis of the borehole pipes). Because of the technological limitations and commercial availability of materials for borehole pipes, polyethylene pipes (HDPE) have been used with a wall thickness of $2.7 \mathrm{~mm}$ to $4.5 \mathrm{~mm}$ and thermal conductivity $0.45 \mathrm{~W} /(\mathrm{m} \cdot \mathrm{K})$. The implementation of the borehole heat exchanger consists of the drilling of the hole, placing borehole tubes in the hole and then filling it with cement slurry from the bottom. It is recommended to apply cement slurry with a high degree of thermal conductivity. The thermal conductivity of the cement slurry changes as many as several times depending on humidity. The cement slurry in a humid state is prepared only based on cement and water, and it has a thermal conductivity of approx. $0.8-1.4 \mathrm{~W} /(\mathrm{m} \cdot \mathrm{K})$. Special recipes of cement slurry are used for borehole heat exchangers. Their thermal conductivity ranges from $1.5 \mathrm{~W} /(\mathrm{m} \cdot \mathrm{K})$ to $2.4 \mathrm{~W} /(\mathrm{m} \cdot \mathrm{K})$. The use of such slurries naturally reduces the thermal resistance and contributes to increasing the efficiency of the borehole heat exchanger. It also results in heat flux transferred between the borehole pipes. The amount of energy that is transfered between the borehole pipes increases with the length of the borehole heat exchanger and the reduced distance between the borehole pipes [6, 7].

In the ideal design of a borehole heat exchanger in the form of a single U-tube, there is no heat transfer between the borehole pipes, the cement slurry has a low thermal resistance and borehole pipes are placed as close as possible to the wall of the hole. In the real BHE there is a flow of energy between borehole pipes. The applied cement slurry has a relatively low thermal conductivity, which generates high thermal resistance, and the borehole pipes are away from the walls at a distance that is required to effectively trip them to the bottom of the hol Figure 1a presents an ideal diagram of a cross-section of a BHE with thermal energy flow directions marked (occurring during the TRT), while in Figure $1 \mathrm{~b}$ gives a view of a real cross-section of BHE, taking into account the heat transfer between borehole pipes.
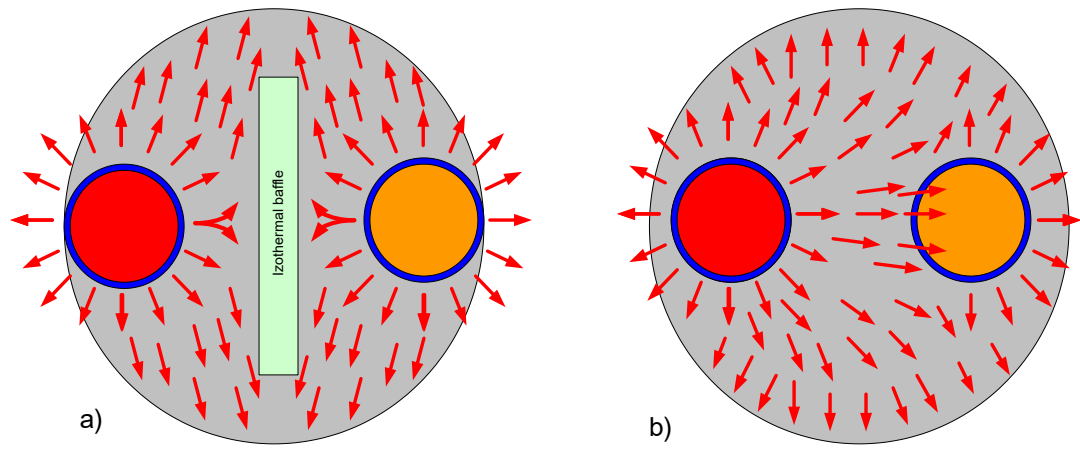

Fig. 1. Scheme of a cross-section: a) ideal BHE with marked imaginable isothermal barrier; b) the real BHE takes into account the heat transfer between borehole pipes 


\section{LABORATORY MODEL OF A BOREHOLE HEAT EXCHANGER}

For describing and measuring the amount of energy which is transferred between borehole pipes, a laboratory BHE model was constructed. It was equipped with temperature sensors of an accuracy of $0.01^{\circ} \mathrm{C}$. The model was isolated from its environment with a $0.05 \mathrm{~m}$ layer of insulating wadding. In the first phase one of the borehole pipes was supplied by the heating factor at a constant temperature. It was realized with a device for TRT with a special application maintaining a constant temperature value. In the first stage, the borehole pipe was located on the whole length of the laboratory model (Fig. 2). In the second step, the polyethylene pipe was removed from the model to eliminate the impact of additional thermal barriers (wall pipe HDPE) on the heat transfer through the BHE model (Fig. 3).

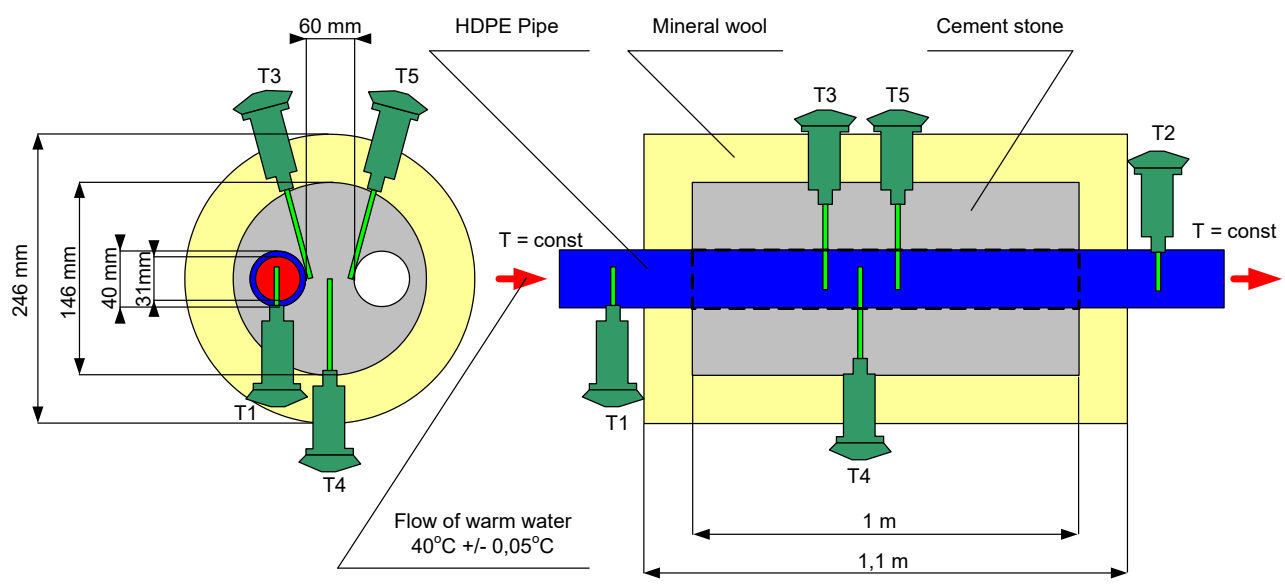

Fig. 2. Laboratory model of a borehole heat exchanger with a scheme of installed sensors (model with a borehole pipe located along its whole length)

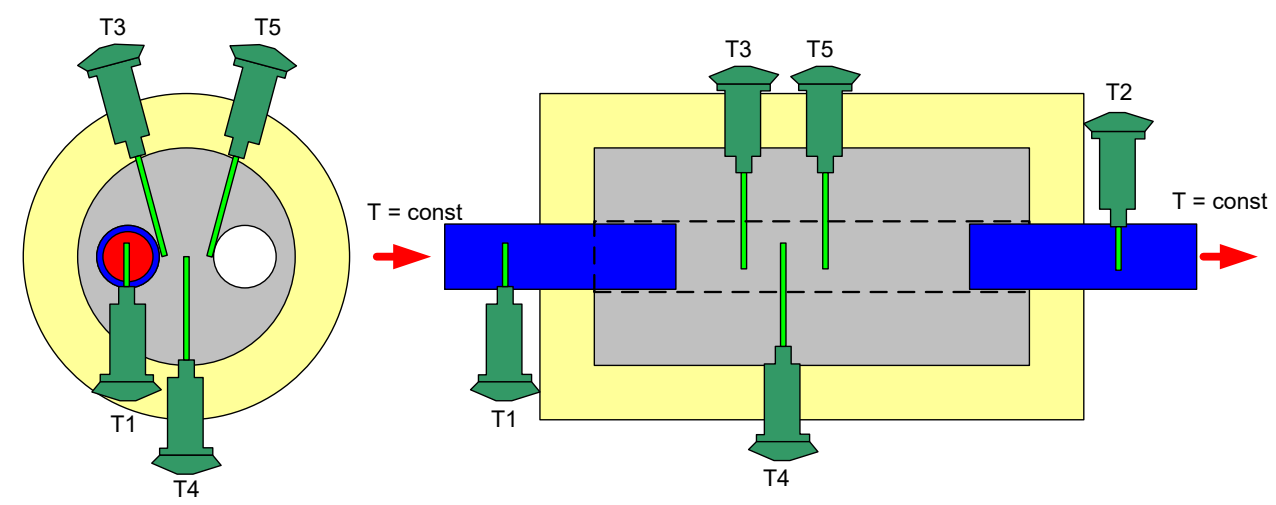

Fig. 3. Laboratory model of a borehole heat exchanger with a scheme of installed sensors (model without a borehole pipe of HDPE in the tested section) 


\section{CARRYING OUT LABORATORY TESTS AND RESULTS}

During testing, the polyethylene borehole pipe was supplied with liquid at $40^{\circ} \mathrm{C} \pm 0.05^{\circ} \mathrm{C}$. The test was performed for wet cement slurry and thermal conductivity of $1.505 \mathrm{~W} /(\mathrm{m} \cdot \mathrm{K})$. In the second phase, the dry model (thermal conductivity of $0.42 \mathrm{~W} /(\mathrm{m} \cdot \mathrm{K})$ ) was used. The thermal conductivity of the cement rock was measured for a wet sample and dried in an oven at $105^{\circ} \mathrm{C}$. The recipe of cement slurry is described in Table 1.

Table 1

Recipes of used sealing slurries

\begin{tabular}{|l|l|}
\hline \multicolumn{1}{|c|}{ Components } & \multicolumn{1}{c|}{ Quantity } \\
\hline Cement CEM I 42.5R & $100 \%$ \\
\hline Sand & $30 \%$ BWOC*$^{*}$ \\
\hline Clay & $3 \%$ BWOC \\
\hline Water & $50 \%$ BWOC \\
\hline
\end{tabular}

*BWOC - mass-relative to the mass of cement

The temperature of the laboratory model was stabilized at a temperature of approx. $22^{\circ} \mathrm{C}$ each time prior to preparing the test. The second phase of the test was to determine the effect of using a polyethylene barrier on the temperature difference registered by the sensors. The results of the tests were recorded at a frequency of one record per second and then averaged at intervals of $30 \mathrm{~s}$. As a result of the measurement, four series were obtained which are shown in Figures 4-7. The final temperature values for the semi-steady state heat transfer are given in Table 2.

The test involved providing the factor at a constant temperature $\left(40^{\circ} \mathrm{C}\right)$ to one borehole pipe of BHE model, in each of the four measurements. At the same time, the sensors recorded the temperature changes until the recorded values were stabilized. This condition allowed for determining the temperature gradient between the interior of the borehole pipes delivering the heat and the wall of the second borehole pipe. Additionally, the time of the heat transfer between the borehole pipes of BHE was measured.

Table 2

Temperature values provided by sensors after reaching the semisteady state

\begin{tabular}{|c|c|c|c|c|}
\hline Number of sensor & $\begin{array}{c}\text { Dry model } \\
\text { with HDPE } \\
\text { pipe } \\
\text { (a) }\end{array}$ & $\begin{array}{c}\text { Dry model } \\
\text { without HDPE } \\
\text { pipe } \\
\text { (b) }\end{array}$ & $\begin{array}{c}\text { Wet model } \\
\text { with HDPE } \\
\text { pipe } \\
\text { (c) }\end{array}$ & $\begin{array}{c}\text { Wet model } \\
\text { without HDPE } \\
\text { pipe } \\
\text { (d) }\end{array}$ \\
\hline Temperature $T_{1}\left[{ }^{\circ} \mathrm{C}\right]$ & 40.03 & 40.02 & 40.02 & 40.05 \\
Temperature $T_{2}\left[{ }^{\circ} \mathrm{C}\right]$ & 40.02 & 40.00 & 40.00 & 40.03 \\
Temperature $T_{3}\left[{ }^{\circ} \mathrm{C}\right]$ & 37.85 & 39.98 & 33.52 & 40.02 \\
Temperature $T_{4}\left[{ }^{\circ} \mathrm{C}\right]$ & 27.75 & 29.33 & 26.59 & 32.93 \\
Temperature $T_{5}\left[{ }^{\circ} \mathrm{C}\right]$ & 22.06 & 23.16 & 22.53 & 28.77 \\
\hline
\end{tabular}




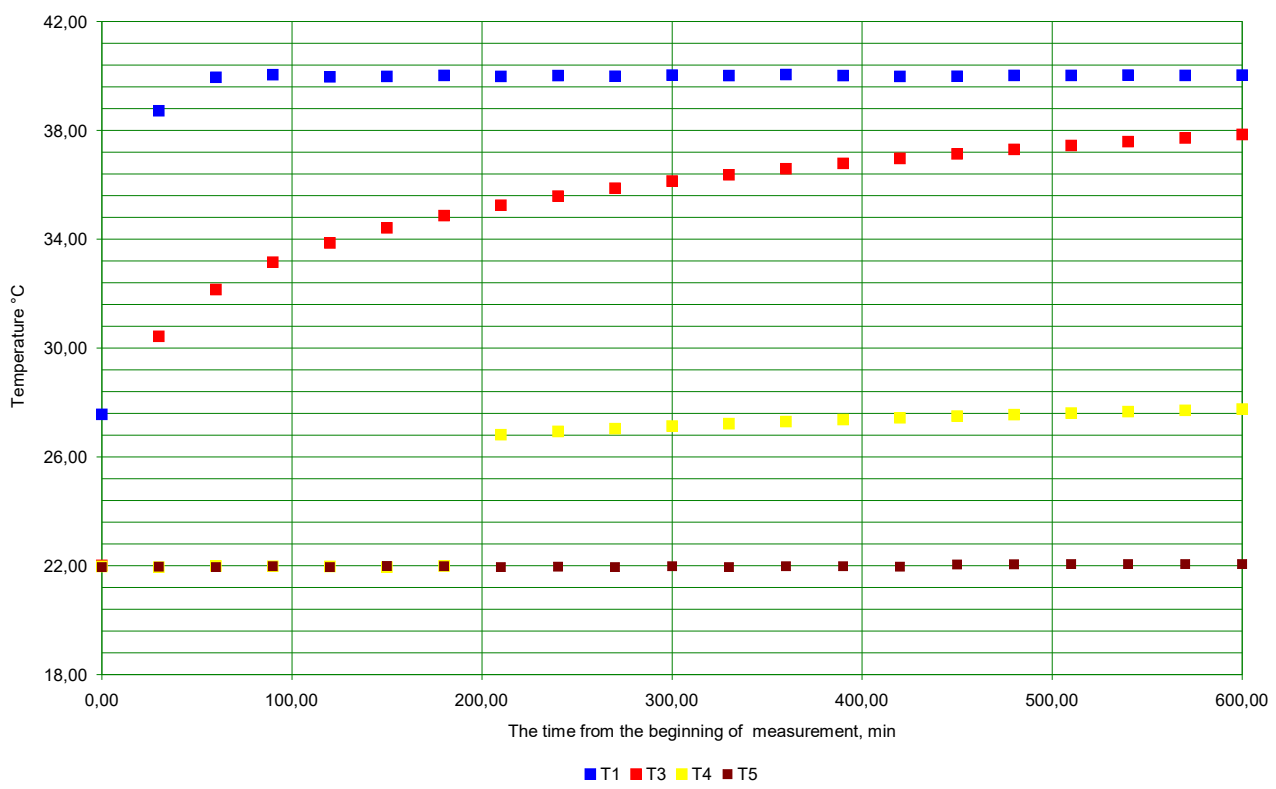

Fig. 4. The course of temperature changes measured for the dry BHE model and when located along the whole length of the HDPE pipe model

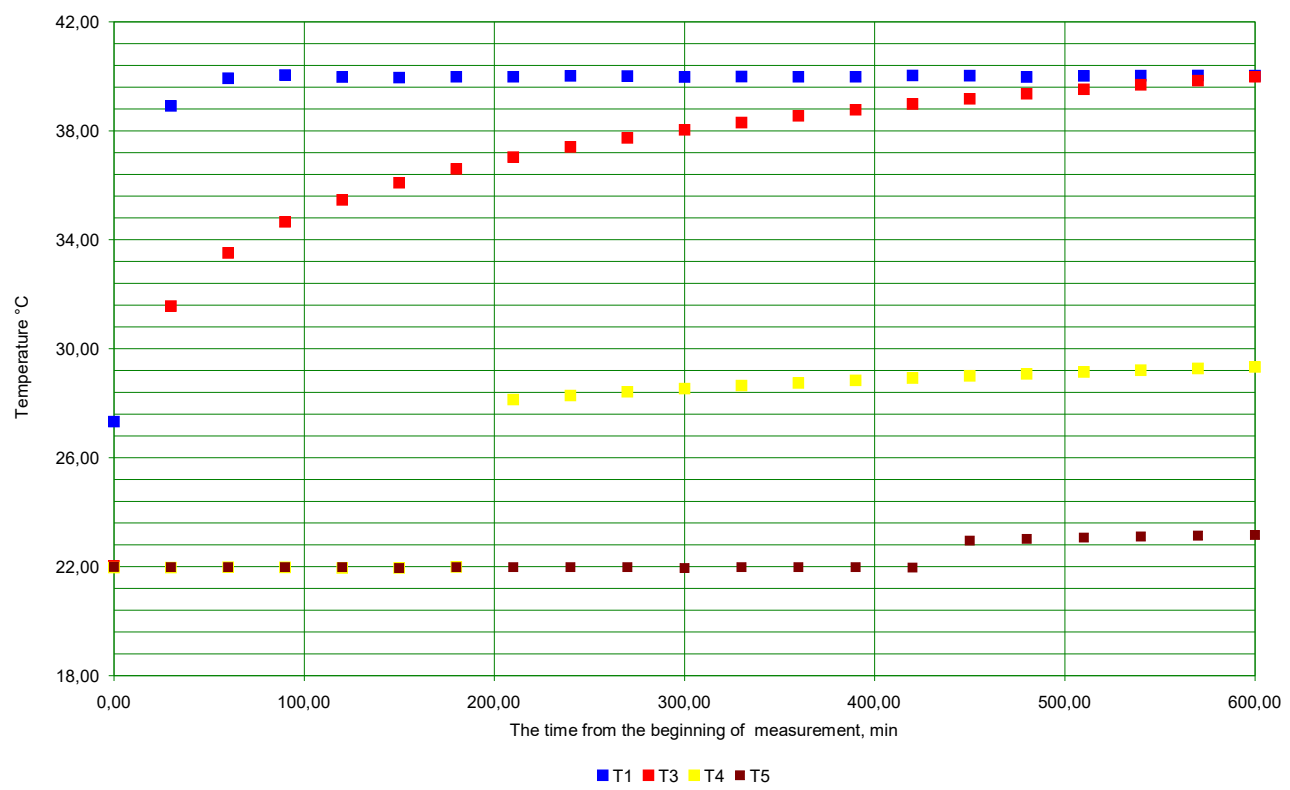

Fig. 5. The course of temperature changes measured for the dry BHE model and with partial localization of the HDPE pipe 


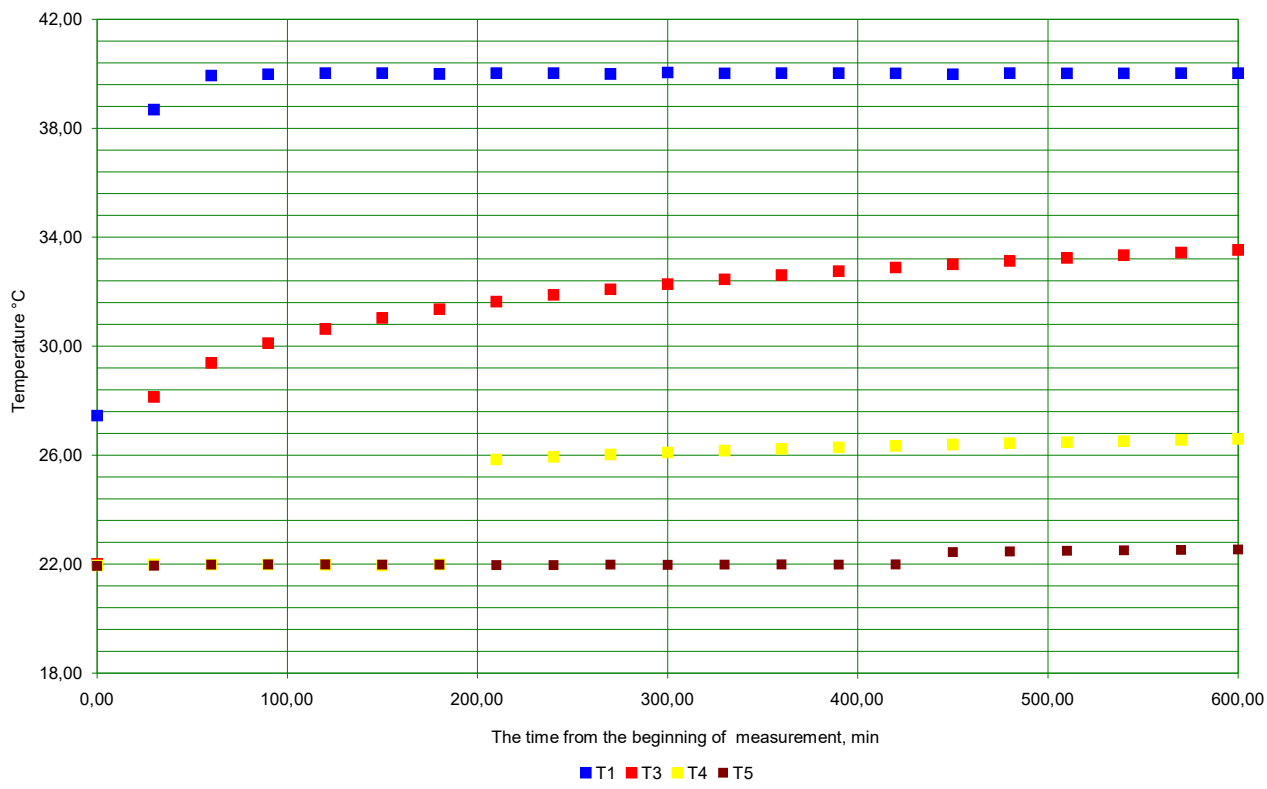

Fig. 6. The course of temperature changes measured for the wet BHE model and when located along the whole length of the HDPE pipe model

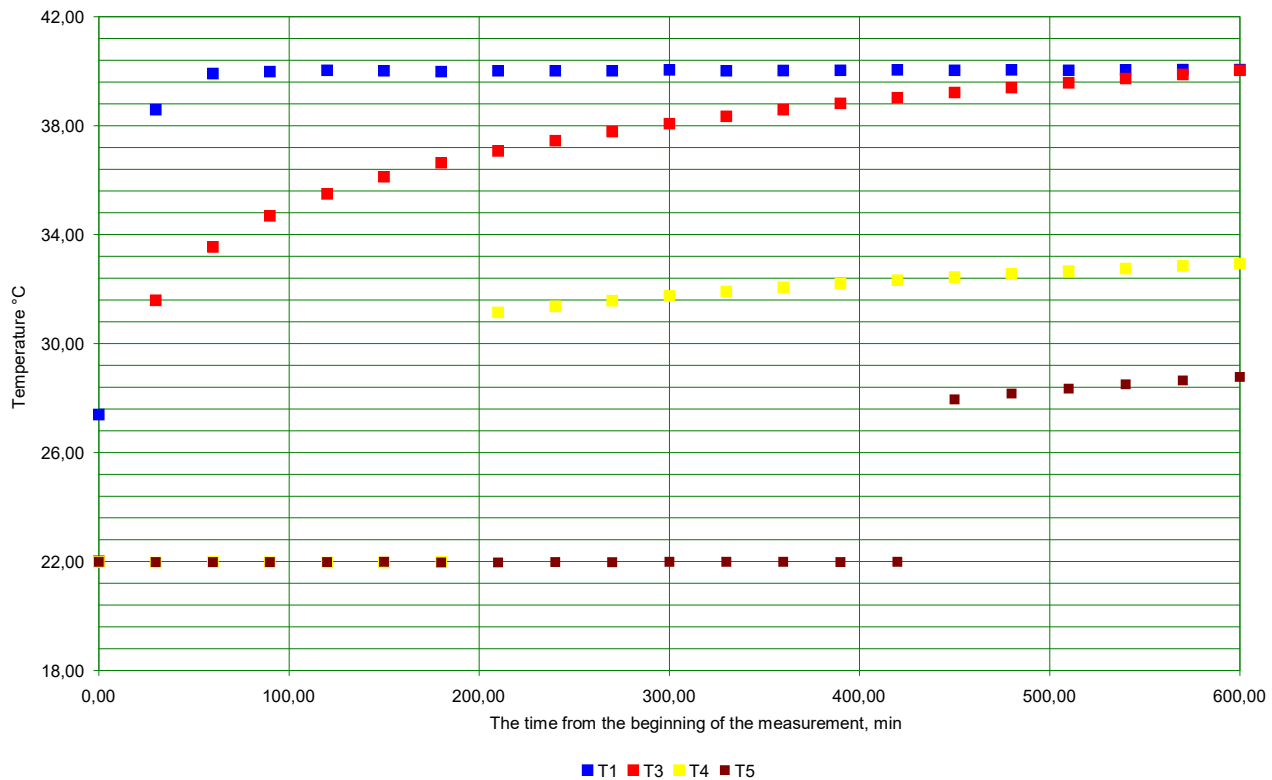

Fig. 7. The course of temperature changes measured for the wet BHE model and with partial localization of the HDPE pipe 


\section{ANALYSIS OF RESULTS}

Based on the results of the measurements, attempts were made to determine the value of the heat flux which is transferred from the source, i.e. borehole pipe delivering heat through its wall, cement slurry and then to the second borehole pipe of BHE. Since the temperature rise was measured with HDPE pipe over the whole length of the model (and installed only partly), the heat flux obtained in the first and the second step of the test could be compared. The calculated value difference allowed for the heat flux to be reduced, which should be additionally taken into account in the case of a real BHE (transfer through the wall of the second borehole pipe). In order to calculate heat flux value in cylindrical systems, the following formula (1) was used:

$$
Q=k \cdot\left(T_{1}-T_{5}\right)[\mathrm{W} / \mathrm{m}]
$$

where:

$k$ - thermal resistance of a multilayer annular barrier obtained from the formula (3 - taking into account the heat transfer coefficient or 2 - without):

$$
\begin{aligned}
& k=\left[\frac{\ln \frac{r_{3}}{r_{2}}}{2 \cdot \pi \cdot \lambda_{z u}}+\frac{\ln \frac{r_{2}}{r_{1}}}{2 \cdot \pi \cdot \lambda_{r}}\right]^{-1}[\mathrm{~W} /(\mathrm{m} \cdot \mathrm{K})] \\
& k_{1}=\left[\frac{1}{\alpha \cdot 2 \cdot \pi \cdot r_{\alpha}}+\frac{\ln \frac{r_{3}}{r_{2}}}{2 \cdot \pi \cdot \lambda_{z u}}+\frac{\ln \frac{r_{2}}{r_{1}}}{2 \cdot \pi \cdot \lambda_{r}}\right]^{-1}[\mathrm{~W} /(\mathrm{m} \cdot \mathrm{K})]
\end{aligned}
$$

$\lambda_{\mathrm{zu}}-$ thermal conductivity of the cement slurry $[\mathrm{W} /(\mathrm{m} \cdot \mathrm{K})]$,

$\lambda_{\mathrm{r}}-$ thermal conductivity of the HDPE pipe $[\mathrm{W} /(\mathrm{m} \cdot \mathrm{K})]$.

Convective heat transfer coefficient $(\alpha)$ is calculated from formula (5) using the Nusselt similarity number (4), which is a function of Reynolds (6) and Prandtl (7) numbers [4, 9]:

$$
\begin{aligned}
& \mathrm{Nu}=f(\mathrm{Re} ; \mathrm{Pr}) \\
& \alpha=\frac{\lambda_{w} \cdot 0.023 \cdot \mathrm{Re}^{0.8} \cdot \mathrm{Pr}^{0.4}}{2 \cdot r_{\alpha}}[\mathrm{W} /(\mathrm{m} \cdot \mathrm{K})] \\
& \operatorname{Re}=\frac{2 \cdot W \cdot \rho_{w}}{\pi \cdot r_{\alpha} \cdot \mu_{w}} \\
& \operatorname{Pr}=\frac{C_{p w} \cdot \mu_{w}}{\lambda_{w}}
\end{aligned}
$$


Radiuses used in the calculations are indicated in Figure 8. The values that are substituted to the formulas and the calculated values of thermal resistance and heat fluxes are shown in Table 3. In order to obtain the same convective heat transfer coefficient (the blue color in Table 3), the volume of water flow was changed in both steps of the test.

In addition, the difference in heat fluxes was calculated and obtained for two cases: with and without the polyethylene pipe. The difference values are presented for the model in the dry and wet states. The resulting difference values of heat flux were given for the dry and wet models with or without convective heat transfer coefficient $(\alpha)\left(\Delta Q_{1}, \Delta Q_{2}, \Delta Q_{11}\right.$, and $\left.\Delta Q_{21}\right)$. Alhough they only differ from one another by about $\pm 10 \%$, they confirm the correctness of the applied measurement method and the calculation. The divergence between these results is due to the slightly different temperature gradients obtained in subsequent measurements.

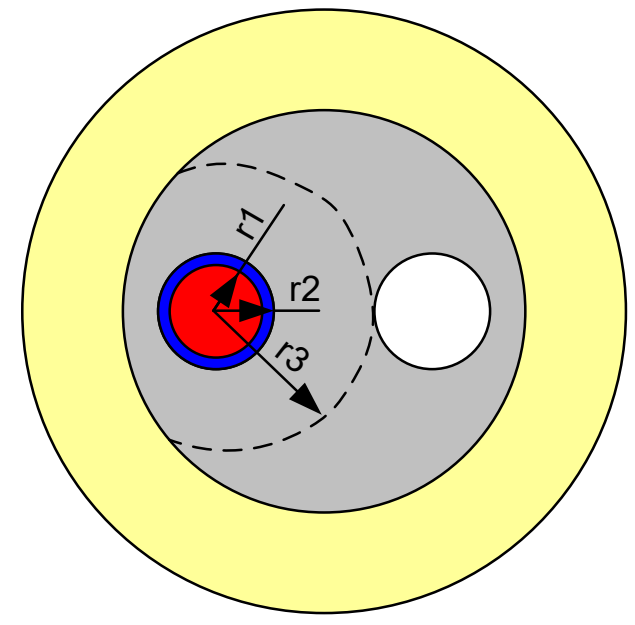

Fig. 8. Scheme of marked radiuses used in the calculation

Table 3

The data used for calculations and results

\begin{tabular}{|l|c|c|c|c|}
\hline \multirow{2}{*}{ Quantity } & \multicolumn{4}{c|}{ Measurement } \\
\cline { 2 - 5 } & $\mathrm{a}$ & $\mathrm{b}$ & $\mathrm{c}$ & $\mathrm{d}$ \\
\hline$T_{1}\left[{ }^{\circ} \mathrm{C}\right]$ & 40.03 & 40.02 & 40.02 & 40.05 \\
\hline$T_{5}\left[{ }^{\circ} \mathrm{C}\right]$ & 22.06 & 23.16 & 22.53 & 28.77 \\
\hline$\lambda_{z u}[\mathrm{~W} /(\mathrm{m} \cdot \mathrm{K})]$ & 0.420 & 0.420 & 1.505 & 1.505 \\
\hline$\lambda_{\mathrm{r}}[\mathrm{W} /(\mathrm{m} \cdot \mathrm{K})]$ & 0.450 & - & 0.450 & - \\
\hline $\mathrm{W}\left[\left(\mathrm{m}^{3} / \mathrm{s}\right)\right]$ & 0.000415 & 0.000736 & 0.000415 & 0.000736 \\
\hline$\lambda_{\mathrm{w}}\left(40^{\circ} \mathrm{C}\right),[\mathrm{W} /(\mathrm{m} \cdot \mathrm{K})]$ & 0.635 & 0.635 & 0.635 & 0.635 \\
\hline$C_{p w}\left(40^{\circ} \mathrm{C}\right),[\mathrm{J} /(\mathrm{kg} \cdot \mathrm{K})]$ & 4174 & 4174 & 4174 & 4174 \\
\hline$\rho_{w}\left(40^{\circ} \mathrm{C}\right),\left[\mathrm{kg} / \mathrm{m}^{3}\right]$ & 992.2 & 992.2 & 992.2 & 992.2 \\
\hline
\end{tabular}




\begin{tabular}{|l|c|c|c|c|}
\hline \multirow{2}{*}{\multicolumn{1}{|c|}{ Quantity }} & \multicolumn{4}{c|}{ Measurement } \\
\cline { 2 - 5 } & $\mathrm{a}$ & $\mathrm{b}$ & $\mathrm{c}$ & $\mathrm{d}$ \\
\hline$\mu_{w}\left(40^{\circ} \mathrm{C}\right),[\mathrm{Pa} \cdot \mathrm{s}]$ & 0.007 & 0.007 & 0.007 & 0.007 \\
\hline$r_{1}[\mathrm{~m}]$ & 0.0155 & - & 0.0155 & - \\
\hline$r_{2}[\mathrm{~m}]$ & 0.0200 & 0.0200 & 0.0200 & 0.0200 \\
\hline$r_{3}[\mathrm{~m}]$ & 0.0800 & 0.0800 & 0.0800 & 0.0800 \\
\hline$r_{\alpha}[\mathrm{m}]$ & 0.0155 & 0.0200 & 0.0155 & 0.0200 \\
\hline $\operatorname{Re}[-]$ & 26016 & 35486 & 26016 & 35486 \\
\hline $\operatorname{Pr}[-]$ & 4.29 & 4.29 & 4.29 & 4.29 \\
\hline $\mathrm{Nu}[-]$ & 140 & 180 & 140 & 180 \\
\hline$\alpha\left[\mathrm{W} /\left(\mathrm{m}^{2} \cdot \mathrm{K}\right)\right]$ & 2863 & 2863 & 2863 & 2863 \\
\hline$k[\mathrm{~W} /(\mathrm{m} \cdot \mathrm{K})]$ & 1.624 & 1.903 & 4.222 & 6.818 \\
\hline$k_{l},[\mathrm{~W} /(\mathrm{m} \cdot \mathrm{K})]$ & 1.615 & 1.893 & 4.159 & 6.691 \\
\hline$Q[\mathrm{~W} / \mathrm{m}]$ & 29.182 & 32.078 & 73.838 & 76.904 \\
\hline$Q_{1}[\mathrm{~W} / \mathrm{m}]$ & 29.014 & 31.909 & 72.740 & 75.469 \\
\hline$\Delta Q_{1}=Q_{b}-Q_{a}=2.896 \mathrm{~W} / \mathrm{m}$ & & $\Delta Q_{2}=Q_{d}-Q_{c}=3.067 \mathrm{~W} / \mathrm{m}$ & \\
\hline$\Delta Q_{11}=Q_{b 1}-Q_{a 1}=2.895 \mathrm{~W} / \mathrm{m}$ & & $\Delta Q_{21}=Q_{d 1}-Q_{c 1}=2.730 \mathrm{~W} / \mathrm{m}$ \\
\hline
\end{tabular}

Source: [10]

The results of heat flux for particular tests refer to the whole circumference of the borehole pipe. To determine which component of the heat flux is directed towards the second borehole pipe, one should determine angle $\alpha$, and which heat flux is actively working on the second borehole pipe (Fig. 9). Angle $\alpha$, for the geometrical parameters of the constructed model, is calculated using the formula (8).

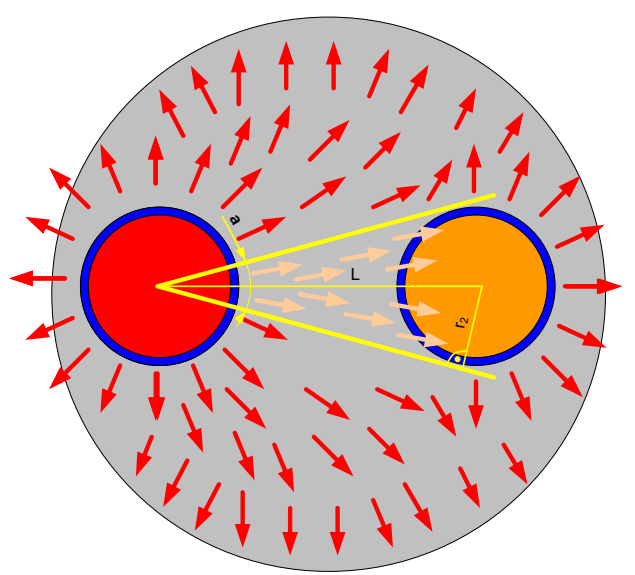

Fig. 9. Scheme to determine angle $\alpha$ (active influence of heat flux on the second borehole pipe) 


$$
\alpha=2 \cdot \arcsin \frac{r_{2}}{L}=22^{\circ} 06^{\prime}
$$

where $L-$ spacing between the borehole pipes $=0.06 \mathrm{~m}$.

Importantly, if we want to know how the heat flux transfers between the borehole pipes of a real BHE, the received difference $\Delta \mathrm{Q}_{2}$ should be subtracted from the heat flux $Q_{c}$. And so, for a BHE in the form of a u-tube, where the distance between the axes of the borehole pipes equals $0.1 \mathrm{~m}$, thermal conductivity of cement slurry $1.505 \mathrm{~W} /(\mathrm{m} \cdot \mathrm{K})$, the value heat flux which is actively involved in the transfer between the BHE pipes can be calculated from the formula (9) for a temperature difference between the borehole pipes equal to $11.28^{\circ} \mathrm{C}$ :

$$
Q_{S}=\frac{\left(Q_{c}-\Delta Q_{2}\right) \cdot \alpha}{360}=4.53[\mathrm{~W} / \mathrm{m}]
$$

The calculated flux value is directly proportional to the temperature difference and this changes with depth BHE. The calculated value provides for the arrangement of the calculation algorithm to determine the heat flux transfer between the borehole pipes in a real BHE.

For example, in a BHE which is $100 \mathrm{~m}$ deep and filled with cement slurry as discussed in the article, with branches spaced by $0.06 \mathrm{~m}$, and a temperature difference between the branches of $4^{\circ} \mathrm{C}$, the heat transfer will exceed $161 \mathrm{~W}$.

\section{CONCLUSIONS}

- The constructed BHE model with temperature sensors allowed for the measuement of the change of the temperature gradient in a radial arrangement, both with an installed and partly installed part polyethylene borehole pipe.

- The heat flux was measured for dry and completely wet cement rock. The differences of the flux value do not exceed 10\% (in two models: with and without borehole pipes), which proves the correctness of the methodology of measuring and processing the results.

- The values of the calculated convective heat transfer coefficient are very similar to the results obtained by omitting this factor.

- The flowing flux energy is much bigger for wet cement rock, when the coefficient of thermal conductivity is several times higher than when the cement slurry is in a dry state.

- The value obtained for the heat flux of wet cement rock applies to the heat transfer of the whole circumference of the borehole pipe. For determining the value of the flux which has been actively influencing the second borehole, one should consider the distance between borehole pipes and their diameter.

- It is possible to achieve a more efficient construction of a heat exchanger in the form of a single u-tube, if an isothermal barrier between borehole pipes is used. 
- The time that was necessary for transferring heat from one borehole pipe to another was $6 \mathrm{~min}$ to $7 \mathrm{~min}$. This means that information on the construction of BHE can be obtained at the initial stage of TRT.

- The information obtained by the heat flux transfer between the borehole pipes can be used for determining the thermal characteristics of the BHE, which was filled with different types of cement rock, had different thermal conductivities and different spacing of borehole pipes.

\section{REFERENCES}

[1] Acuña J., Palm B.: Local Conduction Heat Transfer in U-pipe Borehole Heat Exchangers. Excerpt from the Proceedings of the COMSOL Conference, 2009, Milan.

[2] Gonet A., Śliwa T., Stryczek S., Sapińska-Śliwa A., Jaszczur M., Pająk L., Złotkowski A.: Metodyka identyfikacji potencjału cieplnego górotworu wraz z technologia wykonywania i eksplatacji otworowych wymienników ciepła [Methodology for the identification of potential heat of the rock mass along with technology implementation and operations of the borehole heat exchangers]. Wydawnictwa AGH, Kraków 2010.

[3] Gonet A., Śliwa T, Sapińska-Śliwa A., Złotkowski A, Macuda J.: The analysis of expansion thermal response test (TRT) for borehole heat exchangers. Geothermal reservoir engineering. 37th Workshop, January 30 - February 1, Stanford, California 2012.

[4] Kostowski E.: Zbiór zadań z przepływu ciepła. Wydawnictwo Politechniki Śląskiej, Gliwice 2001.

[5] Miaomiao H.: Numerical Modelling of Geothermal Borehole Heat Exchanger Systems. De Montfort University, Leicester, UK February 2012 [PhD thesis].

[6] Stryczek S., Brylicki W., Wiśniowski R.: Zaczyny uszczelniajace nowej generacji o wysokiej trwałości. Wiertnictwo, Nafta, Gaz, t. 23, 2006, pp. 451-458.

[7] Stryczek S., Małolepszy J., Gonet A., Wiśniowski R., Kotwica Ł.: Wpływ dodatków mineralnych na kształtowanie się właściwości technologicznych zaczynów uszczelniajacych stosowanych $w$ wiertnictwie $i$ geoinzynierii. Wydawnictwo S.C.M.R. Wioska z Chorzowa, Kraków 2011.

[8] Śliwa T.: Badania podziemnego magazynowania ciepła za pomocą kolektorów słonecznych $i$ wymienników otworowych. Wydawnictwa AGH, Kraków 2012.

[9] Wiśniewski S., Wiśniewski T.S.: Wymiana ciepła. Wydawnictwa Naukowo-Techniczne, Warszawa 1997.

[10] Wybrane tablice cieplne. Politechnika Krakowska im. Tadeusza Kościuszki, Wydział Inżynierii Środowiska, Instytut Inżynierii Cieplnej i Ochrony Powietrza, Kraków 2006.

[11] Złotkowski A., Gonet A., Śliwa T.: Otworowe wymienniki ciepła w instalacji grzewczo-klimatyzacyjnej Ekologicznego Parku Edukacji i Rozrywki OSSA. Wiertnictwo, Nafta, Gaz, z. 1-2, t. 28, 2011, pp. 475-482. 